\title{
Simple and cheap photosystem for herbarium digitization
}

\author{
다) Andriy Novikov ${ }^{1}$, 니 Mariia Sup-Novikova ${ }^{2}$ \\ 1 State Museum of Natural History, National Academy of Sciences of Ukraine, Teatralna str. 18, 79008 Lviv, Ukraine; \\ novikoffav@gmail.com \\ ${ }^{2}$ Ukrainian Catholic University, Stryiska str. 29A, 79026 Lviv, Ukraine
}

Received: 21.11.2021 | Accepted: 12.12.2021 | Published online: 14.12.2021

\begin{abstract}
The digitization of the natural history collections is a crucial task of today. It allows not only sharing the data but also virtually preserving the specimens. This is especially important for small collections that suffer from limited financial support and can be easily lost.

Here we share our experience of the building of cheap and simple photosystem that can be used for routine digitization of local herbaria with low or without incomes. This photosystem is modular and based on the regular components that can be easily purchased and/or updated. It is compact and can be conveniently assembled and disassembled, and transported. This photosystem consists of horizontal tripod Beike Q999H with two led lamps Yongnuo YN-300 Air mounted on the 11" Magic Arm handles. The camera Canon EOS 800D was chosen due to presence of fully rotated display, the high resolution, modern focusing system, RAW format support, and low price on the market. The lens Tokina AT-X M35 PRO DX AF $35 \mathrm{~mm}$ f/2.8 Macro was chosen due to extreme sharpness along the whole capturing field, low aberrations and optical distortion, high light sensitivity, and fast autofocus.

We also tested light box as an option for herbarium specimens' digitization. However, we found that light box is inconvenient for herbarium digitization dues several reasons, among which its massive sizes, limited access to working space, and necessity of application of huge mounting system that should hold the camera far higher over the center of light box. In general, work with light box significantly decelerated the digitization process. We did not find any advantaged in use of the light box and therefore it was rejected. We hope that our experience will be useful for other curators wanting to digitize their collections and having limited budget.
\end{abstract}

Keywords: herbarium, digitization, small collections, photosystem construction

Authors' contributions: Novikov A. designed a photosystem and organized the digitization process, and prepared the manuscript. Sup-Novikova M. tested the photosystem, assisted during the digitization, and corrected the manuscript.

Funding: The photosystem for the herbarium digitization was built on the costs of the IAPT Small Collections Grant received by Novikov A. in 2021.

Competing Interests: The authors declare no conflict of interest.

Even today, when modern communication technologies and international transportation system are well developed, many natural history collections remain hidden from scientific community or have limited access due to different reasons. Among the modern 
challenges, restricting the access to natural history collections is COVID-19 pandemic (Baker, 2020). For example, the access to the one of the most valuable collections in Ukraine, the Herbarium of the Ivan Franko National University of Lviv (LW), is fully forbidden for last two years. The access to the biggest herbarium in Ukraine hosted at the M.G. Kholodny Institute of Botany of the NAS of Ukraine (KW) was strongly limited during 2020-2021. Due to pandemic limitations, travel to other countries today can be complicated, what makes access to other collections also questionable.

While the biggest herbaria are, depending on the country, more or less digitized, small collections in many cases are still poorly represented in the databases. At the same time, small herbaria are the most vulnerable due to limited financial support and can be easily lost. Therefore, digitization of such small herbaria is a crucial task providing many research benefits (Holovachov et al., 2014; Cantrill, 2018) and allowing virtually preserve them (Novikov, 2019).

One of such vulnerable collections is the Herbarium of the State Museum of the Natural History of the NAS of Ukraine (LWS) hosting about $118 \mathrm{~K}$ specimens. This is not a small herbarium in a strict sense, but rather a local one (Bridson \& Forman, 2013) covering mostly western part of Ukraine, and representing especially the flora of the Ukrainian Carpathians. Taking into account extremely low budget of our herbarium, it was not possible to purchase such professional digitization solutions as Picturae or Microtek ObjectScan. Therefore, under support of the IAPT Small Collections Grant and considering the recommendations of Takano et al. (2019) we built the simple and cheap photosystem that can be easily applied for routine digitization of the herbarium specimens. Our main requirements to the photosystem were: (1) use of on-the-market components that can be easily purchased and/or updated; (2) modularity, allowing fast replacement of the elements; (3) small size allowing comfortable work in the limited working space.

Fist we tried to use a light box PULUZ PU5060, however very soon we found several critical disadvantages of such solution. First, it is problematic to manipulate with herbarium sheets because only front part of the light box is open - this significantly slower the digitization process. Second, light box does not allow using standard horizontal tripod, because the upper hole is located too far and cannot be reached by normal tripod arm. As a result, it is necessary to build a huge and static mounting system that is expensive and faintly mobile. Third, in case of light box application, the camera appears relatively high and requires use of specific lenses. In particular, we found that sharpness of our lens (i.e., Tokina AT-X M35 PRO DX AF 35 mm f/2.8 Macro) significantly decreased with increased distance from the operating surface. Finally, use of the light box in general requires much more working space.

Therefore, we took our second attempt and decided to renounce the light box application. Instead of this, we built the photosystem basing on the standard horizontal tripod Beike Q999H (Fig. 1A). As a light source, we applied two led lamps Yongnuo YN-300 Air with regulated illumination and two color temperature regimes (3200 and $5600 \mathrm{~K})$. The lamps were mounted directly on the tripod's legs using two 11" Magic Arm handles. The lamps were adjusted to $5600 \mathrm{~K}$-only regime with $60 \%$ of intensity. We also tested use of different light combinations (i.e., with additional diffuse natural (upper left corner) and ceiling light $(6400 \mathrm{~K})$, with additional ceiling light only, and with additional diffuse natural light only). However, this did not influence significantly the quality of obtained results. Influence of a direct natural light was not tested due to absence of such illumination in a working room (windows are located in such a way that strong direct light did not reach the room). Over all, we found that two Yongnuo YN-300 lamps without any additional illumination are enough to obtain adequate results. Just to isolate the photographic area from other room space we installed the matwhite MDF board after the tripod. The tripod was placed over the cutting mat Axent Pro A3.

Additionally, for further image calibration and processing, we applied a ruler with official herbarium logo and X-rite ColorChecker Classic Mini (Fig. 1B). ColorChecker allows calibrating the color balance and white balance, so this also helps to reduce the slightly disproportionate illumination obtained during different working hours. It is preferable to use X-rite ColorChecker Classic Nano, 

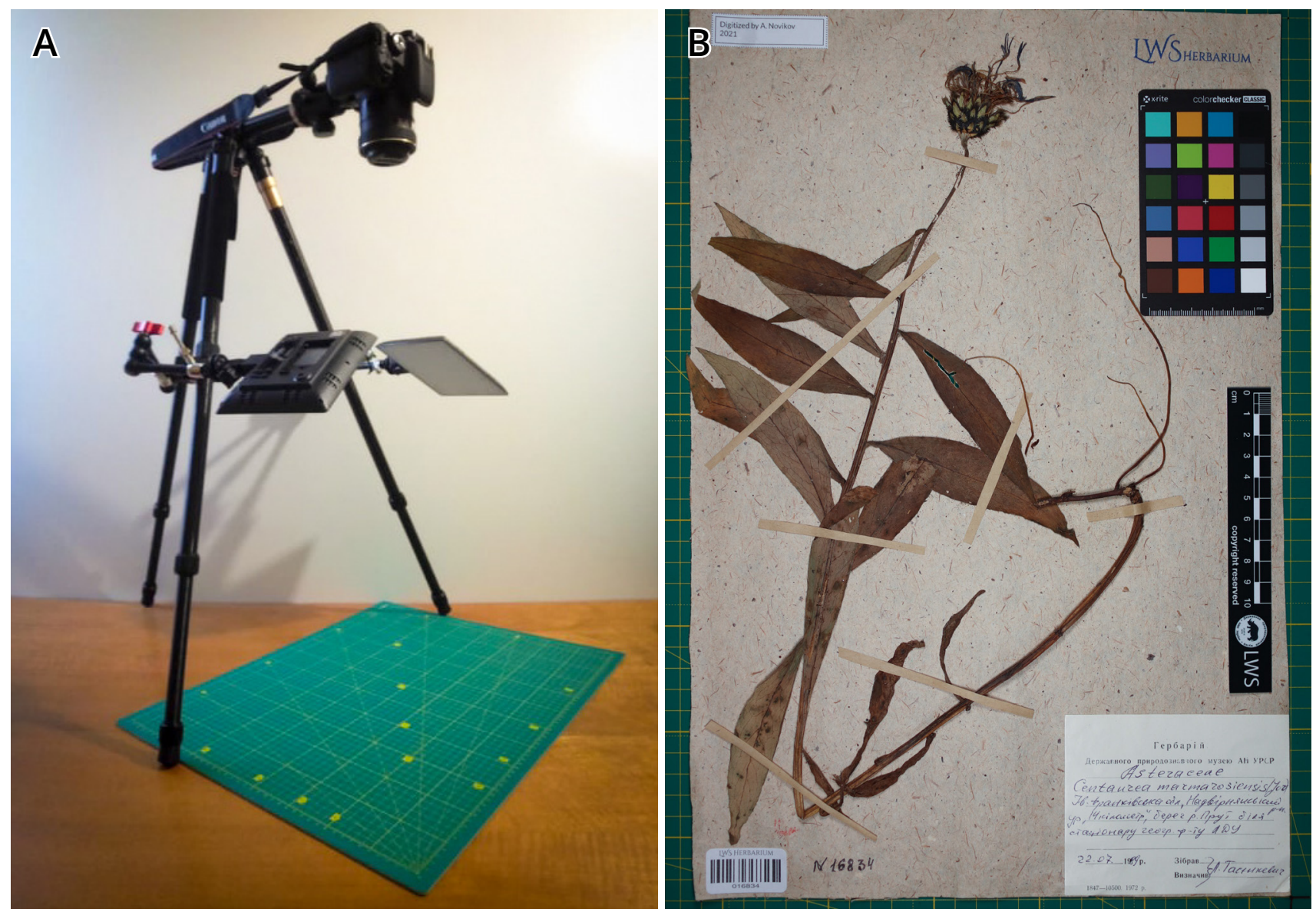

Figure 1. A common view of the photosystem (A) and an example of obtained picture (B).

which is only $22 \times 36 \mathrm{~mm}$ in size. It is more suitable for herbarium digitization because it does not overlap the specimens so much as $\mathrm{X}$-rite ColorChecker Classic Mini $(57 \times 86 \mathrm{~mm})$. However, the price for the smallest version of ColorChecker is almost three times higher, which can be a key decision point if the budget is limited.

We would prefer to use a full-frame camera, but due the limited costs, we choose cropped Canon EOS 800D. The reasons why we chose this camera were: (a) presence of fully rotated display, which is necessary during the horizontal photographing; (b) the high enough resolution (24.2 Mpx); (c) focusing system with 45 focus points allowing quick image capture; (d) RAW format support; (e) low price on the market. The choice of the lens was not so easy. We experimented with zoom (Canon EF-S 18$135 \mathrm{~mm} \mathrm{f} / 3.5-5.6$ IS STM) regular prime (Canon EF $50 \mathrm{~mm} \mathrm{f} / 1.4 \mathrm{USM}$ ) and macro prime (Canon EF $100 \mathrm{~mm} \mathrm{f} / 2.8$ Macro USM and Tokina AT-X M35 PRO DX AF $35 \mathrm{~mm} \mathrm{f} / 2.8$ Macro) lenses. We found that macro lenses produced the sharpest images, while the $35 \mathrm{~mm}$ and $50 \mathrm{~mm}$ lenses had the lowest optical distortion. Finally, we chose Tokina $35 \mathrm{~mm}$ macro lens that also demonstrated low image aberrations, brilliant image sharpness on its whole field, and had two focusing regimes allowing faster picture capturing.

In a result, we obtained a cheap (the whole photosystem costed about 1325 Euros) and easy to use photosystem that can be quickly rebuild or updated, and produces images of high quality. This photosystem can be also easily assembled and disassembled, transported, and do not occupy much of working space. Application of tripod simplify the manipulations with herbarium vouchers, because there is no walls limiting the access. We hope that our experience will be useful for other curators wanting to digitize their collections and having limited budget.

\section{Acknowledgements}

We thank IAPT for providing AN the Small Collections Grant that allowed to start 
digitization of the LWS collection. We also thank Heimo Rainer for consultation, support, and kindly gifted Color Checker.

\section{References}

Baker, B. (2020). Biodiversity collections, data, and Covid. BioScience, 70(10), 841-847. https://doi. org/10.1093/biosci/biaa093

Bridson, D., \& Forman, L. (2013). Herbarium handbook. 3rd edition. Kew Royal Botanic Gardens.

Cantrill, D. J. (2018). The Australasian virtual herbarium: tracking data usage and benefits for biological collections. Applications In Plant Sciences, 6(2), Article e1026. https://doi.org/10.1002/ aps3.1026
Holovachov, O., Zatushevsky A., \& Shydlovsky, I. (2014). Whole-drawer imaging of entomological collections: benefits, limitations and alternative applications. Journal of Conservation and Museum Studies, 12(1), 9. https://doi.org/10.5334/ jcms.1021218

Novikov, A. (2019, November 27-29). Digitization of natural collections - the way to immortality. In Proceedings of the 14th International Young Scientists' Conference "Biology: From a Molecule Up to the Biosphere" (pp. 12-14). Kharkiv. https://doi. org/10.5281/zenodo.3594474

Takano, A., Horiuchi, Y., Fujimoto, Y., Aoki, K., Mitsuhashi, H., \& Takahashi, A. (2019). Simple but long-lasting: a specimen imaging method applicable for small- and medium-sized herbaria. PhytoKeys, 118, 1-14. https://doi.org/10.3897/ phytokeys.118.29434

\title{
Проста й недорога фотосистема для оцифрування гербарію
}

\author{
Андрій Новіков ${ }^{1}$, Марія Суп-Новікова ${ }^{2}$
}

1 Державний природознавчий музей НАН України, вул. Театральна, 18, Львів, 79008, Україна; novikoffav@gmail.com

2 Український католицький університет, вул. Стрийська, 29А, Львів, 79026, Україна

Оцифрування природничих колекцій на сьогодні постає надзвичайно важливим питанням, яке дозволяє не лише поширювати отримані дані, але й віртуально зберігати зразки. Це особливо важливо для малих колекцій, які регулярно потерпають від недофінансування і можуть бути легко втрачені.

В цій публікації ми ділимося досвідом побудови дешевої і простої фотосистеми, що може використовуватися для рутинного оцифрування локальних гербаріїв, які мають обмежений бюджет або й опинилися без фінансової підтримки взагалі. Ця фотосистема $\epsilon$ модульною і побудована на звичних компонентах, які можна легко придбати та/або вдосконалити. Вона $\epsilon$ компактною, зручно складається і розкладається, а також транспортується. Ця фотосистма складається з горизонтального штативу Beike Q999H з двома LED-лампами Yongnuo YN-300 Air змонтованими на 11" тримачах Magic Arm. Камеру Canon EOS 800D було обрано завдяки присутності повністю обертового дисплею, сучасній системі фокусування, підтримці формату RAW, а також низькій ціні на ринку. Об'єктив Tokina AT-X M35 PRO DX AF 35 mm f/2.8 Macro було обрано завдяки винятковій чіткості на всій площині зображення, низькому рівню аберацій та оптичної дисторсії, високій світлочутливості, а також швидкому автофокусу.

Ми також протестували лайт-бокс для оцифрування гербарних зразків. Однак, виявилося, що лайтбокс незручний для оцифрування гербарію з кількох причин. Зокрема, він має великі розміри, обмежений доступ до робочої поверхні, а також вимагає використання масивної несучої конструкції, яка повинна утримувати камеру високо над центром лайт-боксу. Загалом, використання лайт-боксу сильно сповільнює процес оцифрування. Ми не знайшли жодних переваг використання лайт-боксу, і тому відмовилися від його застосування. Ми сподіваємося, що наш досвід буде корисним для інших кураторів, які прагнуть оцифрувати їхні колекції, але мають обмежений бюджет. 